\title{
God's Love and Providence through Nature: Hymnological Analysis and Interpretation of the Hymn "For the Beauty of The Earth" As a Tool
}

\author{
Ricketts, Alaba Opeyemi \\ Faculty of Church Music, Department of Performance, Nigerian Baptist Theological Seminary, Ogbomoso, Nigeria
}

*Corresponding Author

Ricketts, Alaba Opeyemi

\section{Article History}

Received: 26.09 .2020

Accepted: 13.10 .2020

Published: 23.10 .2020

\begin{abstract}
One of the ways that God speaks to and calls attention to himself is through the beauty of nature. The sun, moon, stars, animals in their diversity makes any thoughtful heart begin to wonder how these things came into being and power behind their sustenance. This paper is a hymnological analysis and interpretation of the Hymn "For The Beauty of the Earth" to reveal the love, providence, greatness and awesomeness of God the creator of the universe. It attempts to explore the mind of the lyricist as implied through the hymn text descriptively and theologically to up come with some attributes of God as revealed through creation. This was done through a historical survey of the life of the author, background to the hymn, poetic and hymn text interpretation from which the researcher drew out the author's opinions about God and implications including reasons why humans should respond in gratitude and praise to the kindness of God and in deeds of love to mankind, animals and responsible use and management of the earth.
\end{abstract}

Keywords: God's Love Nature Hymnological Analysis Earth Beauty.

\section{INTRODUCTION}

Though inadequate, nature is certainly one of the ways God calls attention and reveals himself to humanity. Beyond stirring man's curiosity about how things found in nature came about, humanity is led to begin to accept the truism of the existence, awesomeness and majesty of the creator. Many poets and hymn-writers had wondered at nature's awesomeness and written many great hymns that reveal to Christian worshipers the love and majesty of God that ought to stir up in the believer adoration, honour and worship of God. Examples of such hymns as found in Christian hymnody are: "For the Beauty of the Earth," "All Things Bright and Beautiful", "All Creatures of Our God and King", "I sing the Mighty Power of God" and "Great is Thy Faithfulness". Unfortunately, many believers fail to grasp with adequate spiritual perception, the messages conveyed through hymn texts unassisted. Hymnology being a discipline that delves into the historical and scientific study of hymns from both textual and musical viewpoint offers itself a useful tool for the needed assistance (www.encyclopaedia.com>religion)[11]. The hymn: "For the Beauty of the Earth" is one among many that reveal truths for which the Christian believer should be grateful with outburst of praise. This work is aimed at elucidating the awesomeness of God, His love and providence as contained in Folliot Sandford Pierpoint's (1835-1917) [1] lyrics of "For the Beauty of the Earth" as found in the 1991 edition of the Baptist Hymnal [9].

\section{Justification for hymn text interpretation}

Hymn Interpretation comprises an exegesis of the texts of the hymn concerned. Christians are known as "people of the book" and Martin Luther is credited with having given to the people of God the Bible and the hymnbook in their own language. According to Martin Luther, as God speaks to his people through his Word (The Bible), the people can then respond through their songs [2]. It is therefore essential that the worshiper grasps the understanding of the sung text in depth.

Hymn texts consist of words which have been reverently and devotionally conceived. They also describe experiential and expected response of the believer to the word of God [3]. Stories behind several hymns reveal that they

Copyright (C) 2020 The Author(s): This is an open-access article distributed under the terms of the Creative Commons Attribution 4.0 International License (CC BY-NC 4.0) which permits unrestricted use, distribution, and reproduction in any medium for noncommercial use provided the original author and source are credited. 
describe the responses of many heroes of faith to life challenges as Christians. These are not only good but can be instrumental in guiding the contemporary believer to his response to life issues.

Hymn interpretation focuses on the life and exposition of the events culminating in the writing of hymns by their composers and many times they also speak on expected attitude of worshipers towards God, His words and life issues. This makes interpretation of hymns very significant to building the faith and encouragement of the believers and agrees with the Biblical exhortation by Apostle Paul found in Eph. 5:19. "Speak to one another with psalms, hymns, and spiritual songs. Sing and make music in your heart to the Lord." Apostle Paul further states: "Let the word of Christ dwell richly in you as you teach and admonish one another with all wisdom, and as you sing Psalms, hymns and spiritual songs with gratitude in your hearts to God" (Col. 3:16). These passages suggest that lessons and Godly wisdom could be communicated and taught among believers through singing. This is achievable through hymn interpretation.

The believers' rich heritage of experiences of joy and sorrow of the saints, defeat and victories, aspirations, visions and triumphs in life despite challenges and sometimes incapacitation are embodied in the stories of hymns which are exposed for the enrichment of the Christian community through hymn interpretation. These must not be neglected as they serve as a source of strength and inspiration to the believer.

Further in 1Cor. 14: 15-16, Paul the Apostle underscores the importance of praying and singing with understanding. His concern was that the worshipers ought to have proper spiritual perception of what they are singing. This researcher without wishing to slight anyone states that many worshipers' perception and grasp of the rich content of hymn lyrics is further enhanced through the exposition afforded by hymn interpretation.

The stories behind the hymns have a power of ingraining in the hearts of the believer not only the tune but also the truths that are taught by the hymn. Since scriptures are the basic raw materials from which hymns are based, hymn interpretation also becomes a process that aids scriptural truth memorization.

Finally, Christian doctrines and remote figures used in the text of hymns find a means of description in contemporary terms and immediate context of the singers which leads to the worshiper's appreciation of the hymns they love to sing.

\section{HyMnOlogical AnAlysis Biography of the author}

Folliot Sandfort Pierpoint was born in the beautiful resort town of Bath, England on 7 October, 1835, to William Home Pierpoint. The town was adorned with hills and the Avon River that gave to it many natural pools after which it took its name: "Bath". Folliot had the opportunity of good education as his family was quite wealthy. After graduating from grammar school, he attended Queen's College of Cambridge University, graduating in Classsical honours in 1871 (Polman, hymnary.org).

Upon Graduating, He taught at Somersetshire for a short time and pulled out to concentrate on poem and hymn writing as he needed not depend on a job for survival. His wealthy inheritance was sufficient to support him. His reflections on the Biblical text: "Through Jesus therefore, let us continually offer to God a sacrifice of praise- the fruit of lips that openly confess His name"(Heb.13:15)., and the beauty of the countryside that surrounded him inspired him to write the hymn: "For the Beauty of the Earth." $\mathrm{He}$ was 29 years old when he wrote this hymn (dianaleaghmatthews.com)[12].

He contributed three volumes of poetry which were published. His most famous hymn, "For the Beauty of the Earth" which is still sung today, was first published in 1864 in Lyra Eucharistica. He died at the age of eighty-one in Newport England (Polman, Folliot Stanfort Pierpoint (hymnary.org>person>Pierpoint F.S).

\section{Background to the Hymn}

"For the Beauty of the Earth" was written by Folliot Pierpoint in 1864. This hymn depicts the reflection of the composer on the magnificence and aesthetic excellence of Jehovah as revealed through his creation. The composer also considered many aspects of creation which include the earth, skies, trees, and flowers and concludes that man ought to be grateful for these gifts.

Folliot Sandford Pierpoint was motivated to write this hymn when He realized that the Bible encourages the believer to offer sacrifice of praise to God using their voice to utter words that extol Jehovah. This conviction came to him after meditating on Heb. 13:15 "By Him let us offer the sacrifice of praise to God continually that is, the fruit of our lips, and giving praise to His name." As He reflected on the beauty of God's creation, and the sweetness and warmth of love shared between relations and among the brethren, He penned the texts of the hymn. This hymn which was originally 
employed widely as a communion hymn became more famous when the Anglican Church included it among their hymn collection for use during Holy Communion and published it in the hymnal called Lyra Eucharistica in 1864.

Originally, it consisted of eight stanzas with the last line being "This is our sacrifice of praise". As time went on, it became included in other hymnals because of the beauty and depth of thought within its texts with an alteration that made the refrain to read thus: "This our hymn of grateful praise". This was done in order not to limit its use to the Holy Communion service [4, 13]. In the opinion of Bailey (1950, 367-368), the adequacy of the hymn for Holy Communion was significantly obscured by further alteration to the refrain that changed it as shown:

The original refrain was :

Christ our God to thee we raise

This our sacrifice of praise

The new refrain:

Lord of all to thee we raise

This our hymn of grateful praise.

Bailey however agrees that this interpretation is still acceptable as it is in consonance with Heb. 13:15.

\section{Poetic Analysis}

"For the Beauty of the Earth" by F.S. Pierpoint found as hymn number 44 in Baptist Hymnal 1991 edition is a six-stanza poem (sestet) which consists of four lines per stanza with a two-line refrain. The stanzas are rhymed after a consistent rhyming pattern of the ababcc form of alternating final sounds. The hymn is trochaic tetrameter as it begins on the accented downbeat followed by unaccented upbeat and has four of such foot [5].

It consists of six lines of seven syllables each making it a 7.7.7.7.7.7. Meter. The musical meter otherwise known as time signature is four-four and is written in the key of G major. The hymn tune "DIX" is an adaptation by William Henry Monk (1823-1889) of an earlier tune composed by Conrad Kocher (1786-1872) [6].

The lyric is simple and sensuous as it appeals to human senses of beauty through the use of commonplace materials of life as seen in nature for description and appreciation of God's sense of aesthetics, love and care for His creation for which man must give thanks. The hymn also uses poetic devices such as the 'anaphora' as it begins all new stanzas and several of the following phrases with "for". It also makes use of the 'climax' as it progressively describes God's gifts to man, bringing it to a climax with God giving himself as the best gift to humanity.

\section{Interpretation of the Hymn}

Stanza 1:

For the beauty of the earth,

For the glories of the skies,

For the love which from our birth,

Over and around us lies:

\section{Refrain:}

Lord of all, to Thee we raise

This our hymn of grateful praise.

In the first stanza, the poet considered the objects on earth that contribute to its beauty and the splendour of the skies as things that should arouse our gratitude to God. The firmament, having an endless expanse also points to the omnipotence of God. The beautiful foliage, various colours of animals in their endless diversities and roles are sufficient reason for a thoughtful heart to respond in gratitude, honor and reverence to the awesomeness of God the creator of these things. This stanza further motivates one to ponder the greatness of God who sustains and orders all of them by his might and power (Is. 40:26).

The second half of the stanza points to the love of God which is showered on humanity by the bequeathing to man all his creations for his benefit with the responsibility of caring. In addition, God wired man with spectacular innate desire to love their children and care for them.

The poet also referred to this salient point which is a source of affection, warmth and comfort and care within families and to some extent among humans and many animals. This love is enjoyed when available around us (www.godtube.com>popular-hymns)[14]. 


\begin{abstract}
Stanza 2
For the wonder of each hour,

Of the day and of the night,

Hill and vale and tree and flow'r,

Sun and moon and stars of light:
\end{abstract}

\title{
Refrain
}

The second stanza which continues Folliot's appreciation of nature focuses on the cosmos, the orderliness that consistently results in the sequence of day and night and the awesomeness of the creator that sustains it. The array of hills and valleys and the entire universe as specific features for which man must offer praise to God. The diversity of trees and flowers that bud in their seasons. The beauty of foliage, flowers in their varied colors and light from the sun, moon and stars created for the appreciation of the beauties describe the majesty of God for which man stands in awe and wonder of this matchless God.

\section{Stanza 3 \\ For the joy of human love, Brother, sister, parent child, Friends on earth and friends above, \\ For all gentle thoughts and mild:}

\section{Refrain}

The third stanza digresses towards the social dimension, describing the joy derivable from affections that emanate from being a member of a family. It also emphasizes the sacred bonds of human relationships and emotions they engender. Humans are innately wired to love and desire love. Such love that exists between child and parent, brother and sister, and the warmth and comfort of it is what the author describes in this stanza as another great gift of God to humanity. The extent of such love was what prompted the writer of "Song of Songs" to describe love that exists between spouses as delightful and more pleasing than wine thus: "How delightful is your love, my sister, my bride! How much more pleasing is your love than wine, and the fragrance of your perfume more than any spice" (Song of Songs 4:10).

The hymn writer also describes friends above without clearly sayings if he meant angels. However, since scriptures clearly describes occasions that angels were sent to assist men, as in the case of Daniel who received angelic interventions before receiving answers to his prayers, angels could be regarded as friends above in the opinion of this writer (Dan. 10:13). Further corroborating this is the letter of Paul to the Hebrews in which he described angels as ministering spirits to serve those who will inherit salvation (Heb. 1:13-14). The comfort, warmth and relief offered by these heavenly beings regarded as friends above are reasons man should offer to God his sacrifice of praise.

\section{Stanza 4}

For the Church that ever more,

Lifteth holy hands above,

Off'ring up on every shore

Her pure sacrifice of love:

\section{Refrain}

In stanza four the Hymnist appreciated God for his pardoning grace that gave the saints triumphant opportunity to be before God's throne lifting holy hands to Him in praise. The believer's hope to join these in praise evermore though unworthy is another reason why every worshiper must respond to God's love in praise.

\section{Stanza 5}

For the joy of ear and eye,

For the heart's and mind's delight'

For the mystic harmony,

Linking sense to sound and light:

\section{Refrain}

In stanza five, Folliot Pierpoint encourages the believer to consider the gifts of the eye through which he sees nature, the ear, through which sounds are appreciated and mind through which all these are processed for the joy of man. What a great loss it would be if man lacked these organs through which these mysteries can be appreciated.

\section{Stanza 6 \\ For thyself best Gift Divine, \\ To our race so freely giv'n,}


For that great, great love of Thine,

Peace on earth and joy in heav'n

\section{Refrain}

In Stanza six, Folliot Pierpoint turns to God's gift of Himself being the best as illustrated in John 3: 16, “ For God so loved the world that He gave His one and only son that whoever believes in him shall not perish but have eternal life." This divine gift is what gives every believer in Jesus Christ hope after death. How hopeless we would be without such an eternal hope that gives peace on earth and in heaven.

The two omitted stanzas in this hymnal that make the hymn of eight stanzas are historical in themes. They describe theological views of the Church of England's hymn-writers which are not alien to Christianity. The two stanzas are below:

For thy Martyrs's crown of light,

For thy Prophet's eagle eye,

For thy bold confessor's might,

For the lips of infancy:

Refrain:

For thy Virgin's robe of snow,

For thy Maiden-mother mild'

For thyself, with heart aglow,

Jesu, Victim undefiled

Refrain:

Offer we at thine own Shrine

Thyself Sweet sacrament Divine. [7]

The text of the last refrain was adjusted to suit the stanza's text (Hawn, mcdiscipleship.org>resources)[10].

\section{MAN'S RESPONSE AND CONCLUSION}

Appreciate God for the Beauty of Creation

Through scriptures we understand that God is the creator of everything we see, John 1:3, "Through Him all things were made; without him nothing was made that has being made". The account of creation in sequence is found in Genesis chapter one. The hills and vales were created by him, trees, including all land and sea creatures and birds of the air. Then amazingly after God saw that His creations were all good, he displayed unprecedented love when of his own volition, he gave man dominion over all the things he created with a prophetic pronouncement to be fruitful. The account of the prophetic pronouncement is as stated:

(26)Then God said, let us make man in our image, in our likeness, and let them rule over the fish of the sea and the birds of the air, over the livestock, over all the earth and over all the creatures that move along the ground... (28) God blessed them and said to them, "Be fruitful and increase in number; fill the earth and subdue it..." (Gen. 1:26-28).

The sun gives it light during the day, while the stars, decorating the skies with their lights join the moon in beautifully illuminating the earth with moderate light at night. Man ought therefore to respond to God in grateful praise for these things that are sources of beauty and joy around us.

Worship God for Numerous Provisions

Further in Gen. 1: 29, God declared his provision of food for man through his creation. The earth is loaded with everything man needs for survival, the air that we breathe, the water we drink, sun supplies energy to keep man healthy and alive. All through scripture are evidences of the goodness of God to man. Scripture tells us that it is God who gives seed to the sower and bread for food (Eccl. 11:6, 2Cor. 9:10). For these provisions that are never exhausted should man respond in worship and adoration unto God?

Praise God for Sustenance and Guidance

God sustains all creation by His power and in Him are wisdom and power. The scripture attests to this in Job 12: 7-10 \&13, and Chap. 37:14-16 
(7) But ask animals, and they will teach you, or the birds of the air, and they will tell you...(9) which of all these does not know that the hand of the Lord has done this? (10) In His hand is the life of every creature and the breath of all mankind. (13)To God belongs wisdom and power; counsel and understanding are His. (Job 12: 7-10 \&13).

Elihu the friend of Job called him to ponder how God sustains and controls the created order when he said thus:

(14) listen to this, Job; stop and consider God's wonders. (15) Do you know how God controls the clouds and makes His lightening flash? (16) Do you know how the clouds hang poised, those wonders of him who is perfect in knowledge? (Job 37: 14-16).

In Psalm 23, the Psalmist likens Jehovah to a shepherd who leads the sheep to physical and material provisions and also guides spiritually in addition to protection from any kind of harm. God provides for His own, protects and guides them while at the same time sustains the universe. Little wonder then that David exclaimed:"Oh that men will praise the Lord for His goodness and for His wonderful works to the children of men" (Psalm 107:31). Humanity ought to appreciate God through praise for these wonderful services.

Share in Responsibility for Sustenance of the Earth through Creation Care

One of the earliest commands of God is to be responsible to care for the earth. This instruction was to tend and not to only till the ground (Gen. 2: 15). A look at God's order shows that there is a continual system that replenishes the ecosystem. According to Lasebikan [8], the world is endangered today because man focuses on tilling the earth in every way without adequate concern on replenishing. Tree-felling without replanting plans, destruction of wild life and pollution form part of man's carelessness about earth's sustenance.

Love for Humanity and Animals

It cannot be gainsaid that God demonstrates love to humanity. This has been proved through his care for man and his creation. As has been said earlier, God wired man in a way that loves and desires to be loved as seen through affection of parents for their children, among siblings and lovers. God's laws in Scriptures about human co-habitation in communities mostly centre on love for one another. It was for this reason that Jesus Christ summarized the commandments into two thus:

(37)... "Love the Lord your God with all your heart and with all your soul and with your entire mind (38). This is the first and greatest commandment (39). And the second is like it: "Love your neighbour as yourself". ( Matt. 22: 37-39).

God therefore commands man to show and act in love to one another. This love for all creations of God extends to animals by not maltreating them.

Accept that Love is At a Cost and Spread It Wide

Man must recognize that the responsibility to love is not cheap and be prepared to do so to as many people as possible and for as long as required. The fourth stanza of the hymn underscores this.

Accept God's Provision for Salvation

God expects man to respond positively to the best gift which he offers to humanity for the salvation of their souls having been separated through the fall in the Garden of Eden (Gen.3: 1ff). Since the fall, life has been filled with pains and sufferings which made Paul to state in his writing to the Romans that:

(19) The creation waits in eager expectation for the sons of God to be revealed (20). For the creation was subjected to frustration, not by his own choice, but by the will of the one who subjected it in hope (21) that the creation itself will be liberated from its bondage to decay and brought into the glorious freedom of the children of God (Rm. 8:19-21).

Day by day man is confronted with the reality that contrary to pleasant expectation, life experiences are characterized by pains and failures and state of hopelessness. Feeling of insecurity and sicknesses further compound these. For this reason God provides humanity with hope of peace on earth despite the vicissitudes and joy in heaven through Jesus Christ (16). For God so loved the world that he gave His only begotten son that whosoever believes in him will not perish but have everlasting life (John 3:16). God expects humanity to respond to his great provision for salvation with a sense of appreciation that will culminate into praise.

This writer concludes by saying that through nature, the love of God, his majesty and providential power is made manifest through a thoughtful consideration of his creation as exemplified in nature. God's work of creation displays his greatness and love for humanity for which Man ought to respond in gratitude and praise. 


\section{REFERENCES}

1. Polman, B. (2020). Folliot Stanfort Pierpoint hymnary.org>person>Pierpoint_F.S. Accessed 15/09/2020.

2. Bailey, A.E. (1950). The Gospel in Hymns: Backgrounds and Interpretations, New York. Charles Scribner's Sons.

3. Routley, E. (1959). Hymns and Human Life. Michigan, Grand Rapids.

4. Rohm, H.A. (2001). 306 Hymn-writers, Nigeria, Stevarts Graphics.

5. Eskew, H., \& McElrath H.T. (1977). Sing with Understanding: An Introduction to Christian Hymnology Nashville,Church Street Press.

6. McElrath, H.T. (1992). Handbook to the Baptist Hymnal, Nashville, Convention Press.

7. Shipley, O. (1864). Lyra Eucharistica: Hymns and Verses on the Holy Communion. London, Longman.

8. Lasebikan, G.L. (2019). God, Creation and Human Impact in Journal of Creation and Environmental Care. Nigeria, Penthouse Publication.

9. The Baptist Hymnal. (1991). Nashville, Tennessee. Convention Press.

10. Hawn, mcdiscipleship.org>resources. Accessed 26/09/2020.

11. Hymnology. www.encyclopaedia.com>religion Accessed 30/09/2020.

12. Matthews, D.L, Behind the Hymn: "For the Beauty of the Earth" dianaleaghmatthews.com. Accessed on 25/09/2020.

13. The Holy Bible, NIV.

14. www.godtube.com>popular-hymns, For the Beauty of the Earth 2020. 